\title{
Gender Differences in Egyptian Systemic Sclerosis Patients: A Pilot Study
}

\author{
MARWA H. NIAZY, M.D. and HEND H. AL-SHERBENI, M.D. \\ The Department of Rheumatology and Rhabilitation, Faculty of Medicine, Cairo University
}

\begin{abstract}
Background: Some studies have highlighted the role of gender difference in systemic sclerosis (SSc) disease presentation and outcome. Male gender was suggested among poor prognostic factors of the disease.

Aim of Study: To outline gender differences in a retrospective pilot study on $62 \mathrm{SSc}$ patients as regards clinical manifestations, laboratory data and the medications received.

Patients and Methods: This study included 62 SSc patients Their files were retrospectively revised. Demographic data, clinical manifestations, laboratory investigations and medications received during the last visit were recorded. Modified Rodnan skin score (mRss) was used to asses skin tightness.

Results: The patients were $45 / 62$ (72.6\%) females and $17 / 62(27.4 \%)$ males. Their mean age was $40.5 \pm 12.2$ years and mean age of onset was $32.98 \pm 11.4$. The limited subtype represented $67.7 \%$ of SSc patients. Males had higher mRss, but it didn't reach statistical significance $(p=0.11)$. They had statistically significant more frequent arrythmias $(p=0.043)$, and they received statistically significant higher prednisolone doses $(p=0.002)$. Although statistically insignificant, females tended to have a higher frequency of limited cutaneous subtype, pulmonary hypertension, pericardial effusion and calcinosis.

Conclusion: Male SSc patients tended to have more diffuse cutaneous subtype and higher Rodnan score. They had more frequent arrhythmias $(p=0.043)$ and received higher doses of prednisolone $(p=0.002)$. Further longitudinal studies are needed to assess the role of gender difference in presentation, course of disease, response to treatment and outcome in SSc.
\end{abstract}

Key Words: Male gender - Systemic sclerosis - Arrhythmias - Prednisolone.

\section{Introduction}

SYSTEMIC sclerosis (SSc) is a chronic systemic autoimmune disease, characterized by protean manifestations, and overlapping clinical subsets [1]. The common features of SSc are autoimmunity, wide-spread small-vessel vasculopathy, inflamma-

Correspondence to: Dr. Marwa H. Niazy, The Department of Rheumatology and Rhabilitation, Faculty of Medicine, Cairo University tion and progressive interstitial and vascular fibrosis in the skin as well as in internal organs leading to cardiac, pulmonary, gastrointestinal, and renal manifestations [2]. The presence of specific autoantibodies are among the disease hallmarks [3]. SSc is divided into two clinical subsets according to the extent of skin affection. These subsets are the Limited Cutaneous Systemic Sclerosis (lcSSc) and the Diffuse Cutaneous Systemic Sclerosis (dcSSc) [4]. SSc as a part of autoimmune diseases often had a female predominance with an estimated female to male ratio of $\geq 3: 1$, with an increasing incidence among females of child bearing age [5] Gender differences are also involved in the severity of SSc, and male SSc patients have been reported to have more aggressive disease [6,7]. Furthermore, the main causes of death in SSc have been reported to be interstitial lung disease and pulmonary arterial hypertension, and these organ disorders have been reported to be more common and more severe in male SSc patients $[7,8]$. Several factors were supposed to have leading effects on the clinical phenotype according to the sex of SSc patients as hormonal influences, particularly in the childbearing period and pregnancy, genetic predisposition, environmental factors, and social activities. Proof exists for the hormonal factors as higher levels of Interferon (IFN)- $\gamma$ were stimulated by prolactin, and IFN- $\gamma$ was recorded among cytokines stimulating autoimmune disease activity [9-12]. As children exhibited female preponderance as well, genetic factors have been proposed as incomplete or skewed X chromosome inactivation $[12,13]$. Environmental factors were seen in both males and females; including silica-induced scleroderma-like disease, that was mainly encountered among men, and toxin-induced scleroderma-like disease that was more common among women. Cigarette smoking was supposed to be among the factors contributing to the increased frequency and severity of 
interstitial lung disease in males, and to their reduced survival [14]. However, evidence for the role of sex in the clinical manifestations of SSc in patients is still inadequate $[\mathbf{9 , 1 0}]$

The present study aimed to examine gender differences in a retrospective pilot study on sixty two SSc patients as regards clinical manifestations, laboratory data and the medications received.

\section{Patients and Methods}

A retrospective pilot study was conducted on sixty two patients with systemic sclerosis. They all fulfilled the American College of Rheumatology/ European League Against Rheumatism (ACR/ EULAR) classification criteria 2013 for systemic sclerosis [15]. Patients included in this study were following-up at Rheumatology and Rehabilitation Department, Faculty of Medicine, Cairo University Hospitals. The patients' demographic data, clinical manifestations, laboratory investigations and medications received during the last follow-up visit were collected from the medical records \& reported in formulated sheets in-order to identify the disease characteristics and patterns of internal organ involvement. Patients were classified to have diffuse cutaneous SS (dcSSc) or limited cutaneous SSc (lcSSc) according to the scleroderma classification in 1988 [3]. Modified Rodnan skin score (mRss) [16] was used to asses degree and extent of skin tightness of SSc patients. The study was performed in accordance with the Declaration of Helsinki.

\section{Statistical analysis:}

Data were processed and analyzed using the computer program SPSS (the Statistical Package for the Social Science Program) Version 16 for windows (SPSS Inc., Chicago, Illinois, USA). For normally distributed quantitative variables mean \pm standard deviation was used. The median and percentiles were used to describe non parametric data, while frequencies and percentages described qualitative variables. Chi square $(\chi)$ test was performed and Fisher exact test was used when appropriate. Student $(t)$ test was used to compare between parametric data. Mann-Whitney test was used when indicated. $p$-value was considered significant at $<0.05$.

\section{Results}

The present study included $62 \mathrm{SSc}$ patients. They were 45/62 (72.6\%) females and 17/62 (27.4\%) males. Their age ranged from 19 to 75 years with a mean of $40.5 \pm 12.2$ years, the age of onset ranged from 10 to 64 years with a mean of $32.98 \pm 11.4$ years, and disease duration ranged from 0.4 to 24 years with a mean of $7.5 \pm 5.7$ years. The limited subtype represented 42/62 (67.7\%), while 20/62 (32.3\%) had diffuse subtype. The clinical features, laboratory characteristics and medications received are shown in (Tables 1-3). The male SSC patients tended to have a higher mRodnan score $(p=0.11)$, and more frequent interstitial lung disease $(p=0.16)$. However, without statistical significance. They were found to have a statistically significant higher frequency of arrhythmias $(p=0.043)$. Female SSC patients had a higher frequency of systemic hypertension, limited subtype presentation, pulmonary hypertension, pericardial effusion and calcinosis, but it didn't reach statistical significance ( $p>0.05)$ (Tables 4,5). Males had more frequent positive antinuclear antibody, but without statistical significance ( $p=0.47$ ). They received more statistically significant higher doses of prednisolone ( $p=0.002$ ), and more cyclophosphamide and methotrexate, but without statistical significance ( $p=0.26$ and $p=0.37$ respectively) (Table 6).

Table (1): Demographic features and comorbidities in systemic sclerosis patients.

\begin{tabular}{lc}
$\begin{array}{l}\text { Variable } \\
\text { mean } \pm \text { SD or } \mathrm{n}(\%)\end{array}$ & $\begin{array}{c}\text { Systemic sclerosis } \\
\text { patients }(\mathrm{n}=62)\end{array}$ \\
\hline Sex: & $45(72.6 \%)$ \\
Females & $17(27.4 \%)$ \\
Males & $40.5 \pm 12.2$ \\
Age (years) & $32.98 \pm 11.4$ \\
Age at onset (years) & $7.5 \pm 5.7$ \\
Disease duration (years) & $8(12.9 \%)$ \\
DM & $16(25.8 \%)$ \\
Hypertension &
\end{tabular}

DM: Diabetes Mellitus.

Table (2): Clinical manifestations in systemic sclerosis patients.

\begin{tabular}{ll}
\hline $\begin{array}{l}\text { Variable } \\
\text { mean } \pm \text { SD or n }(\%)\end{array}$ & $\begin{array}{c}\text { Systemic sclerosis } \\
\text { patients }(\mathrm{n}=62)\end{array}$ \\
\hline - Subtype: & \\
$\quad$ Limited & $42(67.7 \%)$ \\
$\quad$ Diffuse & $20(32.3 \%)$ \\
- ILD & $39(62.9 \%)$ \\
- Pulmonary hypertension & $21(33.9 \%)$ \\
- Cardiac involvement (valve disease-pericardial & $29(46.8 \%)$ \\
effusion-arrythmias) & \\
- Pericardial effusion & $9(14.5 \%)$ \\
- Arrhythmias & $6(9.7 \%)$ \\
- Pitting scars & $39(62.9 \%)$ \\
- Ischemic digital lesions & $23(37.1 \%)$ \\
- Telangiectasia & $9(14.5 \%)$ \\
- Calcinosis & $9(14.5 \%)$ \\
- Arthritis & $24(38.7 \%)$ \\
- Myositis & $18(29 \%)$ \\
- Renal involvement & $7(11.3 \%)$ \\
- mRodnan score & $13.03 \pm 4.3$ \\
\hline ILD $\quad$ Interstitial Lung Disease. & \\
mRodnan score: Modified Rodnan Score. &
\end{tabular}


Table (3): Laboratory characteristics and treatment received by systemic sclerosis patients.

\begin{tabular}{|c|c|c|c|}
\hline \multicolumn{2}{|l|}{ Variable } & \multicolumn{2}{|c|}{$\begin{array}{l}\text { Systemic sclerosis } \\
\text { patients }(\mathrm{n}=62)\end{array}$} \\
\hline \multicolumn{2}{|c|}{ ESR mm/1st hour (mean $\pm \mathrm{SD}$ ) } & \multicolumn{2}{|l|}{$42.1 \pm 31.6$} \\
\hline \multicolumn{2}{|c|}{$\mathrm{Hb}$ gm/dl $($ mean $\pm \mathrm{SD})$} & \multicolumn{2}{|l|}{$11.7 \pm 1.99$} \\
\hline \multicolumn{2}{|c|}{$\mathrm{WBC} \times 10^{3} / \mathrm{mm}^{3}($ mean $\pm \mathrm{SD})$} & \multicolumn{2}{|l|}{$7.7 \pm 3.5$} \\
\hline \multicolumn{2}{|c|}{ Platelets X $10^{3} / \mathrm{mm}^{3}$ (mean \pm SD) } & \multicolumn{2}{|l|}{$273.9 \pm 98.7$} \\
\hline \multicolumn{2}{|c|}{ ALT U/L median (IQR) } & \multicolumn{2}{|c|}{$18.5(11-30.5)$} \\
\hline \multicolumn{2}{|c|}{ Creatinine $\mathrm{mg} / \mathrm{dl}$ median (IQR) } & \multicolumn{2}{|c|}{$0.7(0.58-0.8)$} \\
\hline \multicolumn{2}{|l|}{ UTI n (\%) } & \multicolumn{2}{|c|}{$11 \quad(17.7 \%)$} \\
\hline \multicolumn{2}{|l|}{ Positive ANA $(\mathrm{n}=50)$} & \multicolumn{2}{|c|}{$39 / 50(78 \%)$} \\
\hline \multicolumn{2}{|l|}{ Cyclophosphamide $\mathrm{n}(\%)$} & \multicolumn{2}{|c|}{$32(51.6 \%)$} \\
\hline \multicolumn{2}{|l|}{ Azathioprine $\mathrm{n}(\%)$} & \multicolumn{2}{|l|}{$30(48.4 \%)$} \\
\hline \multicolumn{2}{|c|}{ Methotrexate n $(\%)$} & \multicolumn{2}{|l|}{$22(35.5 \%)$} \\
\hline \multicolumn{2}{|c|}{ Mycophenolate mofetil n (\%) } & \multicolumn{2}{|l|}{$7 \quad(11.3 \%)$} \\
\hline \multicolumn{2}{|c|}{ Anticoagulant therapy n (\%) } & \multicolumn{2}{|l|}{$11(17.7 \%)$} \\
\hline \multicolumn{2}{|c|}{ Prednisolone median (IQR) } & \multicolumn{2}{|l|}{$6 \quad(5-10)$} \\
\hline \multicolumn{4}{|c|}{$\begin{array}{l}\text { ESR : Erythrocyte Sedimentation Rate. } \\
\text { Hb : Hemoglobin. } \\
\text { WBC : White Blood Cells. } \\
\text { ALT : Alanine Transferase. } \\
\text { UTI : Urinary Tract Infection. } \\
\text { ANA : Antinuclear Antibodies. }\end{array}$} \\
\hline \multicolumn{4}{|c|}{$\begin{array}{l}\text { Table (4): Differences in demographic features and comorbid- } \\
\text { ities between females and males. }\end{array}$} \\
\hline $\begin{array}{l}\text { Variable } \\
\text { mean } \pm \mathrm{SD} \text { or } \mathrm{n}(\%)\end{array}$ & $\begin{array}{c}\text { Females } \\
(n=45)\end{array}$ & $\begin{array}{l}\text { Males } \\
(\mathrm{n}=17)\end{array}$ & $\begin{array}{c}p- \\
\text { value }\end{array}$ \\
\hline Age (years) & $41.3 \pm 12.1$ & $38.7 \pm 12.6$ & 0.46 \\
\hline Age at onset (years) & $33.5 \pm 11.2$ & $31.7 \pm 12.2$ & 0.58 \\
\hline Disease duration (years) & $7.76 \pm 5.9$ & $6.79 \pm 5.9$ & 0.56 \\
\hline $\mathrm{DM}$ & $5(11.1 \%)$ & $3(17.6 \%)$ & 0.67 \\
\hline Hypertension & $14(31.1 \%)$ & $2(11.8 \%)$ & 0.19 \\
\hline
\end{tabular}

DM: Diabetes Mellitus.

Table (5): Differences in clinical manifestations between females and males.

\begin{tabular}{llll}
\hline $\begin{array}{l}\text { Variable } \\
\text { mean } \pm \text { SD or } \mathrm{n}(\%)\end{array}$ & $\begin{array}{l}\text { Females } \\
(\mathrm{n}=45)\end{array}$ & $\begin{array}{l}\text { Males } \\
(\mathrm{n}=17)\end{array}$ & $\begin{array}{c}p \text { - } \\
\text { value }\end{array}$ \\
\hline Limited/diffuse subtype & $32 / 13$ & $10 / 7$ & 0.38 \\
& $(71.1 \% / 28.9 \%)$ & $(58.8 \% / 41.2 \%)$ & \\
ILD & $27(60 \%)$ & $12(70.6 \%)$ & 0.16 \\
Pulmonary hypertension & $30(66.7 \%)$ & $11(64.7 \%)$ & 1.00 \\
Heart valves involvement & $21(46.7 \%)$ & $8(47.1 \%)$ & 1.00 \\
Pericardial effusion & $9(20 \%)$ & $0(0)$ & 0.053 \\
Arrhythmias & $2(4.4 \%)$ & $4(23.5 \%)$ & 0.043 \\
Pitting scars & $27(60 \%)$ & $12(70.6 \%)$ & 0.56 \\
Ischemic digital lesions & $16(35.6 \%)$ & $7(41.1 \%)$ & 0.7 \\
Telangiectasias & $6(13.3 \%)$ & $3(17.6 \%)$ & 0.7 \\
Calcinosis & $8(17.8 \%)$ & $1(5.9 \%)$ & 0.4 \\
Arthritis & $17(37.8 \%)$ & $7(41.2 \%)$ & 1.00 \\
Myositis & $10(22.2 \%)$ & $8(47.1 \%)$ & 0.067 \\
Renal involvement & $5(11.1 \%)$ & $2(11.8 \%)$ & 1.00 \\
mRodnan score & $12.5 \pm 3.97$ & $14.5 \pm 4.9$ & 0.11 \\
\hline ILD & 5 & &
\end{tabular}

ILD : Interstitial Lung Disease.

mRodnan score: Modified Rodnan score.

$p$-value is significant at $<0.05$.
Table (6): Laboratory features and medications received in females and males systemic sclerosis patients.

\begin{tabular}{|c|c|c|c|}
\hline Variable & $\begin{array}{l}\text { Females } \\
(n=45)\end{array}$ & $\begin{array}{l}\text { Males } \\
(\mathrm{n}=17)\end{array}$ & $\begin{array}{c}p- \\
\text { value }\end{array}$ \\
\hline ESR mm/1st hour (mean \pm SD) & $41.7 \pm 30.9$ & $43.2 \pm 34.4$ & 0.87 \\
\hline $\mathrm{Hb}$ gm/dl $\left(\right.$ mean $\left._{3} \pm \mathrm{SD}\right)$ & $11.6 \pm 1.7$ & $12.04 \pm 2.6$ & 0.42 \\
\hline WBC X10\%/mm (mean \pm SD) & $7.5 \pm 3.5$ & $8.2 \pm 4.5$ & 0.49 \\
\hline Platelets X10 $/ \mathrm{mm}$ (mean \pm SD) & $271.5 \pm 89.04$ & $280.4 \pm 123.6$ & 0.79 \\
\hline ALT U/L median (IQR) & $17(12-30)$ & $22(7.5-55)$ & 0.77 \\
\hline Creatinine mg/dl median (IQR) & $0.7(0.59-0.8)$ & $0.7(0.5-0.8)$ & 0.62 \\
\hline UTI n (\%) & $8(17.8 \%)$ & $3 \quad(17.6 \%)$ & 0.65 \\
\hline Positive ANA $(n=39 / 50)$ & $\begin{array}{l}25 / 34 \\
(73.5 \%)\end{array}$ & $\begin{array}{l}14 / 16 \\
(87.5 \%)\end{array}$ & 0.47 \\
\hline Cyclophosphamide $\mathrm{n}(\%)$ & $21(46.7 \%)$ & $11(64.7 \%)$ & 0.26 \\
\hline Azathioprine n (\%) & $22(48.9 \%)$ & $8(47.1 \%)$ & 1.00 \\
\hline Methotrexate n $(\%)$ & $14(31.1 \%)$ & $8(47.1 \%)$ & 0.37 \\
\hline Mycophenolate mofetil n (\%) & $5 \quad(11.1 \%)$ & $2(11.8 \%)$ & 1.00 \\
\hline Prednisolone dose & $5 \quad(5-8.75)$ & $\begin{array}{l}10 \\
(6.25-13.75)\end{array}$ & 0.002 \\
\hline
\end{tabular}

ESR : Erythrocyte Sedimentation Rate.

$\mathrm{Hb}$ : Hemoglobin. UTI : Urinary Tract.

WBC : White Blood Cells. ANA : Antinuclear Antibodies.

ALT : Alanine Transferase. $\quad p$-value is significant at $<0.05$.

\section{Discussion}

Several studies have introduced mixed results concerning the role of gender in predisposition for several relevant clinical manifestations, in onset and along the course of disease; including digital ulcers, cardiac involvement and pulmonary hypertension. Moreover, it was indefinite whether differences in age of onset existed between both sexes, and there were inconsistent results regarding gender differences in the survival when considering SScassociated causes of death. Many of these issues probably were subjected to geographical variations and environmental factors that diverged between studies $[\mathbf{1 0 , 1 7 , 1 8 ]}$. The impact of gender difference on systemic sclerosis disease remains to be elucidated. So, this study aimed to examine gender differences in a retrospective pilot study on $62 \mathrm{SSc}$ patients as regards clinical manifestations, laboratory data and the medications received.

The patients were 45/62 (72.6\%) females and $17 / 62(27.4 \%)$ males in a ratio of $2.6: 1$. This is slightly lower than previous results 3-4.6:1 [19-21] Even a higher ratio was reported in other studies 5-9.7:1 [14,22-24]. Females were documented to be at higher risk for SSc than males reaching 14:1 $[25,26]$. Patients' ages ranged from 19 to 75 years with a mean of $40.5 \pm 12.2$ years, their age at disease onset ranged from 10 to 64 years with a mean of $32.98 \pm 11.4$ years, and the disease duration ranged from 0.4 to 24 years with a mean of $7.5 \pm 5.7$ years. This demographic distribution agrees with a previous study in Egypt conducted by Abdel Moneim et al., [19] as they reported mean age of $36.2 \pm 13.9$ (17-70) years, and mean age of disease onset of 
$29.8 \pm 13.1$ (9-67) years. On the other hand, in other ethnic groups, Lo Monako et al., [26] recorded in a study of SSc in an area in north-eastern Italy a higher mean age of diagnosis of 59.7 (median 62, range $22-83$ years), and others recorded a mean age of $55.9 \pm 13.3$ years, and mean age of onset of $46.2 \pm 12.9$ years [23]. In this study the lcSSc subtype represented $42 / 62(67.7 \%)$ in a ratio of $2.1: 1$. Previous studies reported a frequency ranging between 1.4-6:1 [21,23,24,26] . Contrarily, other authors reported dcSSc to be more frequent than lcSSc 1.5-2.3:1 [20,27].

Male SSc patients were slightly younger than females at the onset of their disease. In contrast to Nguyen et al., [28] who reported age of onset in females to be $46.1 \pm 12.7$ years, compared to $46.7 \pm$ 14.4 years in males. Females had higher frequency of $\mathrm{lcSSc}$ presentation while males were more prone to have the dcSSc, but this didn't reach statistical significance. This is consistent with a previous publication presented by Peoples et al., [14] who compared gender differences in SSc patients in a large single-center cohort study in United States of America (USA) including a total of $2686 \mathrm{SSc}$ patients. Similarly, other authors reported higher frequency of lcSSc in females [29-31]. Opposite to these findings, other investigators from Spain recorded no disease cutaneous subtype difference by gender $[32,33]$. Modified Rodnan skin score tended to be higher in males ( $p=0.11)$, but without statistical significance. In support, a significantly higher skin score was recorded in males in a previous study [14]. In the current study, males had statistically significant more frequent arrhythmias $(p=0.043)$. Although statistically non significant, males had tendency for more frequent ILD ( $p=$ 0.16 ), ischemic digital lesions ( $p=0.7)$, telangiectasias $(p=0.7)$, arthritis $(p=1.00)$ and myositis $(p=$ 0.067 ), while females had more frequent systemic hypertension $(p=0.19)$, pulmonary hypertension $(p=1.00)$, pericardial effusion $(p=0.05)$, and calcinosis $(p=0.4)$, but without statistical significance. Previous studies [19] reported similar results, as they stated that the females had a higher frequency of pulmonary hypertension, pericardial eff-usion and systemic hypertension $(18 \%, 6.6 \%, 9.8 \%$ respectively), whereas none of them was recorded in males. However, unlike our results females had more frequent ILD (55.7\% compared to $42.9 \%)$. Other studies found that males were more prone to have both ILD and pulmonary Hypertension, and they concluded that male gender was among poor prognostic factors $[14,29]$. Consistent with our results, Joven et al., [33] found more frequent arrhythmias and inflammatory muscle diseases. Pitting scars and digital ulcers were more found in males in one study [29], arthritis and myositis were more frequent in males in another study [14], while calcinosis was found more frequent in females in others $[\mathbf{1 9 , 2 9 ]}$. The difference in findings between various studies could be explained by the different sample size and other racial factors.

It is noteworthy to mention that although statistically non significant, positive ANA tended to be more frequent in males $(p=0.47)$, similar to results reported by other authors [14].

In this study, males received statistically significant higher doses of prednisolone $(p=0.002)$, and they received more cyclophosphamide and methotrexate, but without statistical significance ( $p=0.26, p=0.37$ respectively), which indicated that males were more prone to have a more severe disease course requiring more aggressive treatment. This is supported by the findings presented by Carreira et al., [34] in a cross-sectional analysis of the prospective EULAR scleroderma trial and research database (EUSTAR). They concluded that in the early stages of SSc, men presented with more severe disease manifestations.

In this study, we experienced some limitations, as the data of 62 patients were obtained retrospectively. Our sample size was relatively small, and our inability to demonstrate statistically significant differences between the two groups might be due to the lack of statistical power. Further studies are required in order to confirm the observed gender difference.

\section{Conclusion:}

Gender differences may provide important evidence establishing a better understanding of the natural history and pathogenesis of SSc. In females, SSc appeared to occur in a relatively older age and more likely to be of the limited subtype. In contrast, in males SSc appeared to occur at a rather younger age, more likely to be of the diffuse subtype, and they had statistically significant higher frequency of arrhythmias, and more prednisolone doses were required to control the more aggressive disease.

\section{Conflict of interest:}

None.

\section{References}

1- VARGA J.: Systemic sclerosis an update. Bulletin of the NYU Hospital for Joint Dis, 66 (3): 198-202, 2008.

2- VARGA J. and ABRAHAM D.: Systemic sclerosis: A prototypic multisystem fibrotic disorder. J. Clin. Invest., 117 (3): 557- 67, 2007. 
3- PENNY R.: Scleroderma: Pathogenic factors and current treatment. Aust. N. Z. J. Med., 1: 143-48. 1979.

4- LEROY E.C., BLACK C., FLEISCHMAJER R., et al.: Scleroderma (systemic sclerosis): Classification, subsets and pathogenesis. J. Rheumatol., 15 (2): 202-5, 1988.

5- STEEN V.D., ODDIS C.V., CONTE C.G., et al.: Incidence of systemic sclerosis in Allegheny County, Pennsylvania. A twenty-year study of hospital-diagnosed cases, 19631982. Arthritis Rheum., 40 (3): 441-5, 1997.

6- MEDSGER T.A.: Classification, prognosis. In: Clements, PJ., Furst, DE., editors. Systemic sclerosis. 2 nd. Philadelphia: Lippincott, Williams \& Wilkins: 17-28, 2004.

7- GAULTIER J.B., HOT A., CATHÉBRAS P., et al.: Systemic sclerosis in men. Rev. Med. Interne., 29 (3): 1816, 2008.

8- STEEN V.D. and MEDSGER T.A.: Changes in causes of death in systemic sclerosis, 1972-2002. Ann. Rheum. Dis., 66 (7): 940-4, 2007.

9- CLEMENTS P.J., LACHENBRUCH P.A., SEIBOLD J.R., et al.: Skin thickness score in systemic sclerosis: An assessment of interobserver variability in 3 independent studies. J. Rheumatol., 20 (11): 1892-6, 1993.

10- ABAITUA B.I., PHILEN R.M., POSADA P.M., et al.: Toxic oil syndrome mortality: The first 13 years. Int. J. Epidemiol., 27: 1057-63, 1998.

11- SU D.L., LU Z.M., SHEN M.N., et al.: Roles of pro-and anti-inflammatory cytokines in the pathogenesis of SLE. J. Biomed. Biotechnol., 347141. Doi: 10.1155/2012/ 347141, 2012.

12- MALLAMPALLI M.P., DAVIES E., WOOD D., et al.: Role of environment and sex differences in the development of autoimmune diseases: A roundtable meeting report. Journal of Women's health, 22 (7): 578-86, 2013.

13-QUINTERO O.L., AMADOR-PATARROYO M.J., MONTOYA-ORTIZ G., et al.: Autoimmune disease and gender: Plausible mechanisms for the female predominance of autoimmunity. J. Autoimmun., 38: J109-19, 2012.

14- PEOPLES C., MEDSGER T.A., LUCAS M., et al.: Gender differences in systemic sclerosis: Relationship to clinical features, serologic status and outcomes. J. Scleroderma. Relat. Disord., 1 (2): 177-240, 2016.

15- VAN DEN HOOGEN F., KHANNA D., FRANSEN J., et al.: Classification criteria for systemic sclerosis: An American college of rheumatology/european league against rheumatism collaborative initiative. Ann. Rheum. Dis., 72: 1747-55, 2013

16- CLEMENTS P., LACHENBRUCH P., SIEBOLD J., et al.: Inter and intraobserver variability of total skin thickness score (modified Rodnan TSS) in systemic sclerosis. J. Rheumatol., 22: 1281-5, 1995.

17- HUSSEIN H., LEE P., CHAU C., et al.: The effect of male sex on survival in systemic sclerosis. J. Rheumatol., 41: 2193-200, 2014.

18- ELHAI M., AVOUAC J., WALKER U.A., et al.: A gender gap in primary and secondary heart dysfunctions in systemic sclerosis: A EUSTAR prospective study. Ann. Rheum. Dis., 75: 163-9, 2016.

19- ABD EL-MONEIM G., DARWEESH H., ISMAEL M., et al.: Frequency of disease subsets and patterns of organ involvement among Egyptian patients with systemic sclerosis-A retrospective study. Egypt Rheumatol., 35: 145-9, 2013.

20- TAGER R.E. and TIKLY M.: Clinical and laboratory manifestations of systemic sclerosis (scleroderma) in Black South Africans. Rheumatology, 38 (5): 397-400, 1999.

21- PAGALAVAN L. and ONG S.G.: Demography, clinical and laboratory features of systemic sclerosis in a Malaysian rheumatology centre. Med. J. Malaysia, 62 (2): 117-21, 2007.

22- MUKERJEE D., ST GEORGE D., COLEIRO B., et al.: Prevalence and outcome in systemic sclerosis associated pulmonary arterial hypertension: Application of a registry approach. Ann. Rheum. Dis., 62: 1088-93, 2003.

23- ALAMANOS Y., TSIFETAKI N., VOULGARI P.V., et al.: Epidemiology of systemic sclerosis in Northwest Greece 1981 to 2002. Semin Arthritis Rheum., 34 (5): 714-20, 2005.

24- WALKER U.A., TYNDALL A., CZIRIJAK L., et al.: Clinical risk assessment of organ manifestations in systemic sclerosis-a report from the EULAR scleroderma trials and research (EUSTAR) group data base. Ann. Rheum. Dis., 66 (6): 754-63, 2007.

25- GABRIELLII A., AVEDIMENTO E.V. and KRIEG T.: Scleroderma. N. Engl. J. Med., 360: 1989-2003, 2009.

26- LO MONACO A., BRUSCHI M., LA CORTE R., et al.: Epidemiology of systemic sclerosis in a district of Northern Italy. Clin. Exp. Rheumatol., 29 (65): S10-4, 2011.

27- WANG J., ASSASSI S., GUO G., et al.: Clinical and serological features of systemic sclerosis in a Chinese cohort. Clin. Rheumatol., 32 (5): 617-21, 2013.

28- NGUYEN C., BÉREZNÉ A., BAUBET T., et al.: Association of gender with clinical expression, quality of life, disability, and depression and anxiety in patients with systemic sclerosis. PLoS. One, 6 (3): e17551-7, 2011.

29- FERRI C., VALENTINI G., COZZI F., et al.: Systemic Sclerosis Study Group of the Italian Society of Rheumatology (SIR-GSSSc). Systemic sclerosis: Demographic, clinical, and serologic features and survival in 1012 Italian patients. Medicine (Baltimore), 81 (2): 139-53, 2002.

30- AL-DHAHER F.F., POPE J.E. and OUIMET J.M.: Determinants of morbidity and mortality of systemic sclerosis in Canada. Semin Arthritis Rheum., 39: 269-77, 2010.

31- HESSELSTRAND R., SCHEJA A. and AKESSON A.: Mortality and causes of death in a Swedish series of systemic sclerosis patients. Ann. Rheum. Dis., 57: 6826, 1998.

32- SIMEON C.P., CASTRO-GUARDIOLA A., FONOLLOSA V., et al.: Systemic sclerosis in men: Clinical and immunological differences. Br. J. Rheumatol., 35: 910$1,1996$.

33- JOVEN B., ALMODOVAR R. and CARREIRA P.E.: Gender differences in systemic sclerosis clinical expression and survival [abstract]. Ann. Rheum. Dis., 65: 395, 2006.

34- CARREIRA P., CARMONA L., JOVE B., et al.: Gender differences in early systemic sclerosis patients: A report from the EULAR scleroderma trials and research group (EUSTAR) database. Clin. Exp. Rheumatol., 36 suppl 113 (4): 68-75, 2018 


\section{أختلافات الجنس فى مرضى تصلب الجلد الجهازى المصريين:

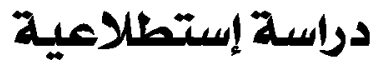

لقد ألقت بعض الدراسات الضوء على أختلافات الجنس فى مقدمات ونتائج مرض تصلب الجلد الجهازى وكان جنس الذكر مقترحاً بين

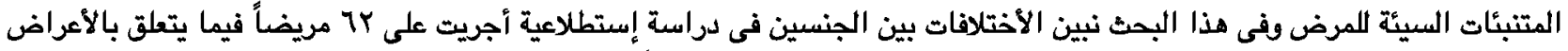

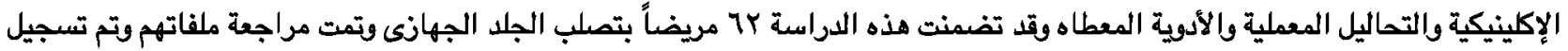

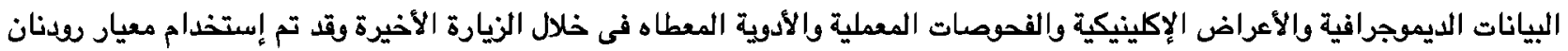
الجلدى لتقييم تييس الجلد ونتج عن الدراسة الآتى:

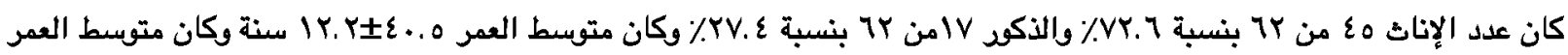

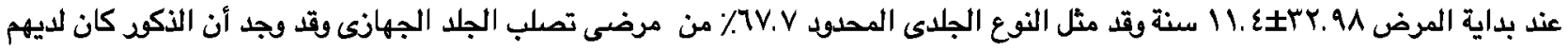

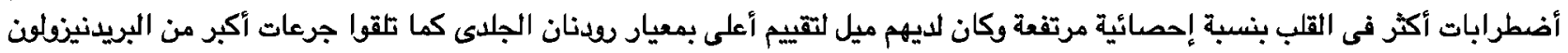

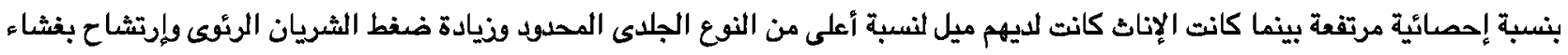

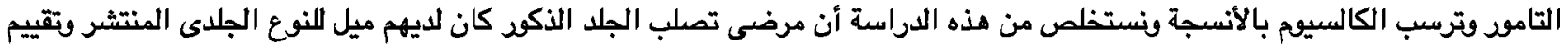

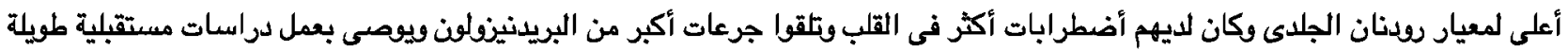

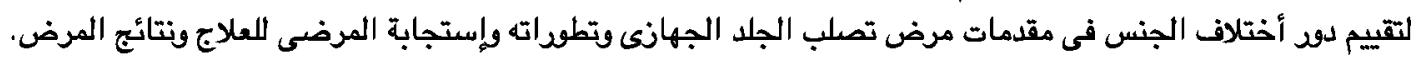

